$$
\begin{gathered}
\text { カーボンナノチューブのコヒーレントフォノン } \\
\text { 加藤 景子*1 · 北島 正弘*2 }
\end{gathered}
$$

\title{
Coherent Phonons in Carbon Nanotubes
}

\author{
Keiko KATO*1 and Masahiro KITAJIMA*2 \\ ${ }^{* 1}$ NTT Basic Research Laboratories, Nippon Telegraph and Telephone Corporation, 3-1 Morinosato Wakamiya, Atsugi, \\ Kanagawa 243-0198, Japan \\ *2Department of Applied Physics, School of Applied Science, National Defense Academy of Japan, Hashirimizu 1-10-20, Yokosuka, \\ Kanagawa, 239-8686, Japan
}

(Received August 25, 2009, Accepted October 10, 2009)

\begin{abstract}
Carbon nanotubes have potential to make breakthrough achievement in nano-electronics, photonics, and ultrafast devices. We report real-time observations of coherent phonons in aligned single-walled carbon nanotubes through the time-resolved reflectivity measurements with sub-10 fs laser pulses. In the isotropic reflectivity measurements, we observe the radial breathing modes, $G$ and even $\mathrm{D}$ modes, while in the anisotropic reflectivity measurements, only the $\mathrm{G}$ mode appears. A complex polarization dependence of the $\mathrm{G}$ band phonon amplitude in the isotropic reflectivity indicates the superposition of $\mathrm{G}$ band phonons with different symmetries.
\end{abstract}

\section{1. はじめに}

「半導体の集積密度は，およそ18～24か月で倍増する」. 1965年に提唱されたムーアの法則に牽引され，半導体デバ イスは微細化の一途をたどった ${ }^{1)}$.今ではその動作速度は $\mathrm{GHz}$ を超え, キャリアの散乱時間に迫る領域にまで到達し ている. 結果, デバイスの大きさは原子レベルにまで到達 し, 従来の半導体技術の延長のみでは同法則の限界を迎える 日もそう遠い将来ではなくなってきた．この問題を解決する $1 つ の$ 可能性として, グラフェン2)やカーボンナノチュー ブ3)などの炭素系材料に大きな注目が集まっている.

カーボンナノチューブ (carbon nanotube/CNT) は炭素 原子からなる自然形成の量子細線で，グラファイトの層を円 筒状に丸めた構造をもつ. 円周方向の周期的境界条件によっ て量子化された電子状態は, 丸め方に応じて半導体にも金属 にもなるという著しい性質をもつ ${ }^{4,5)}$. チューブの直径は 1 $\mathrm{nm}$ 程度で, シリコン半導体の微細構造よりも100分の 1 程 度細い.ナノオーダの 1 次元構造は, キャリアの運動方向 を限定し，CNTではバリスティック伝導（キャリアが無散 乱で走行する）に近い電子輸送を可能とする ${ }^{6)}$.

ナノチューブのもうひとつの特徵に, 超高速光応答が挙げ られる. CNTに光を照射すると, 光励起キャリアが生成さ れる. その後, キャリア・キャリア散乱, キャリア・フォノ ン散乱によって励起キャリアは数百フェムト秒以内に緩和す $ろ^{7-9)}$. 光応答は CNTの 1 次元構造を反映し, 空間的に強 い非等方性を示す10-14). このような CNT の非等方かつ超高 速光過程を利用して, 超高速光通信を目指した光スイッチン グデバイス ${ }^{15)}$ や超短パルスレーザ16-18)への応用研究が行わ れている，その実現に当たっては，CNTを光で制御するこ

*1 NTT 物性科学基礎研究所（干243-0198 神奈川県厚木市森の 里若宮 3-1)

E-mail: kkato@will.brl.ntt.co.jp

*2 防衛大学校応用物理学科（干239-8686 神奈川県横須賀市走水 1-10-20)
とが必要となり, CNTの超高速光過程の物理や特性を正し く理解することが必要不可欠である.

CNTのキャリアやフォノンのダイナミクスは, 超短パル スレーザを用いたポンプ・プローブ分光計測を通じて追跡す ることができる7-9,19). 特にフォノンに関しては, 格子振動 周期の半分より短い時間幅を持つ超短パルスレーザを照射す ることで, 位相の揃った格子振動, コヒーレントフォノン (coherent phonon) として観測できる ${ }^{20-22)}$. コヒーレント フォノンを観測することでフォノンの励起・減衰 ${ }^{20)}$ のダイ ナミクスやフォノンの位相 23,24$)$ など定常状態の観測では得ら れない情報がわかる. なたレーザの波形整形技術を用いれば フォノンの振幅を制御することも出来る ${ }^{24,25)}$.

我々はサブ10フェムト秒レーザを用い，単層カーボンナ ノチューブの時間分解反射率の測定を行い, カーボンナノチ ューブのコヒーレントフォノンを観測した ${ }^{22)}$. 本稿では, 2 章でカーボンナノチューブの基本物性, 3 章でコヒーレント フォノンの測定原理, 実験装置に触れ，4章でカーボンナノ チューブのコヒーレントフォノンの観測結果とその意味する ところについて述べようと思う.

\section{2. カーボンナノチューブ}

本章ではカーボンナノチューブのフォノン物性を理解する に当たり, 必要な基本知識に関して述べる。 2.1節で電子構 造, 2.2 節でフォノン物性に関して説明する。

\section{1 電子構造}

ナノチューブを構成する円筒面はグラファイトの六格子面 （グラフェン）であり，グラフェンシートの巻き方（chirality/螺旋度）次第で任意の螺旋構造をもつことができる ${ }^{4,5)}$. ナノチューブの電子構造はグラフェンの $\pi$ バンドのエネル ギー分散を基本とし，その螺旋度に応じた周期的境界条件を 課すことで得られる. その結果, チューブ軸に垂直な方向で は電子の波数が量子化され, CNT のエネルギー状態は離散 的になる ${ }^{4,26,27)}$. Fig. 1 にナノチューブの電子構造と立体構 造を示す27-29). ナノチューブの立体構造に依存して, エネ 
ルギーギャップのない金属（Fig. 1(a))，またはギャップの ある半導体になるのがわかる (Fig. 1(b)).

さらに，ナノチューブの電子構造で特徵的なのは 1 次元 物質に特有なファンホーブ特異性 (van Hove singularity) である ${ }^{4,26,27,29)}$. ファンホーブ特異が起きると特異点で状態 密度が発散する. Fig. 1 で, 特異点に対応してCNTの状態 密度がところどころでするどいピークを持っているのがわか る. この特異点の間で光吸収が起きると, 分子の吸収のよう な鋭い吸収スペクトルが得られる.ここで光の偏光が CNT 軸に平行な場合には, フェルミ面を中心に対称な特異点の間 で強い光吸收 26 )が起き (antenna effect/アンテナ効果) ${ }^{30)}$, 垂直な場合には，その吸収は抑制される（depolarization effect/偏光解消効果) ${ }^{31}$. この 2 つの特異点のエネルギー差 （遷移エネルギー）は螺旋度によって異なる，片浦はさまざ まな螺旋度を持つCNTについて, 直径と遷移エネルギーの 関係を示した（Kataura plot/片浦プロット） ${ }^{32,33)}$. Fig. 2 に 片浦プロットを示す.片浦プロットから，大半の CNT が可 視領域で吸収を持つことがわかる，また同じ直径でも金属 $\mathrm{CNT}$ と半導体 CNT で遷移エネルギーが異なることから， 励起光の波長を変えることで半導体と金属を選択的に励起す

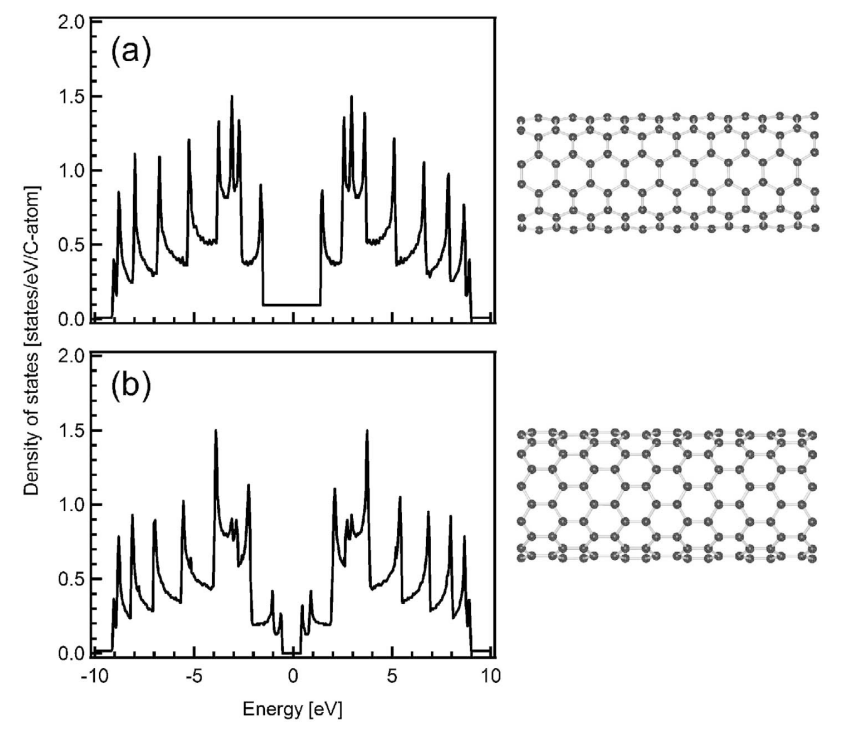

Fig. 1 Electronic density of states for (a) a metallic nanotube and (b) a semiconducting nanotube. Data points are taken from Ref. 29. The right figures show corresponding structures.
ることができる.

\section{2 フォノン}

CNT の格子振動はグラファイトの基準振動が基本となっ ている. CNT では円周方向に周期的境界条件が加わること から, グラファイトのフォノンの分散曲線を折り曲げる (zone folding/ゾーンフォールディング) ことでCNT のフ オノンの分散曲線が得られる ${ }^{5,34)}$. その結果, グラファイト では光学的に許容されていなかった振動数が，CNT ではブ リルアン領域の中心である $\Gamma$ 点（フォノンの波数 $: q=0)$ で新たな振動モードとして許容になる (Fig. 3(a) -3(d)).

CNT のフォノン物性は, これまで主にラマン分光によっ て調べられてきた ${ }^{35,36)}$. ラマン分光では連続レーザ光を入射 光として用い, 試料からの散乱光の強度を入射光と散乱光の エネルギー差の関数で表示する．前述のと抢り，CNT は可 視領域に吸收を持つので, 入射光として可視域のレーザを用 いると共鳴ラマン効果（resonance Raman effect）が起き， ラマン強度が増強される.こうして得られた周波数領域の久

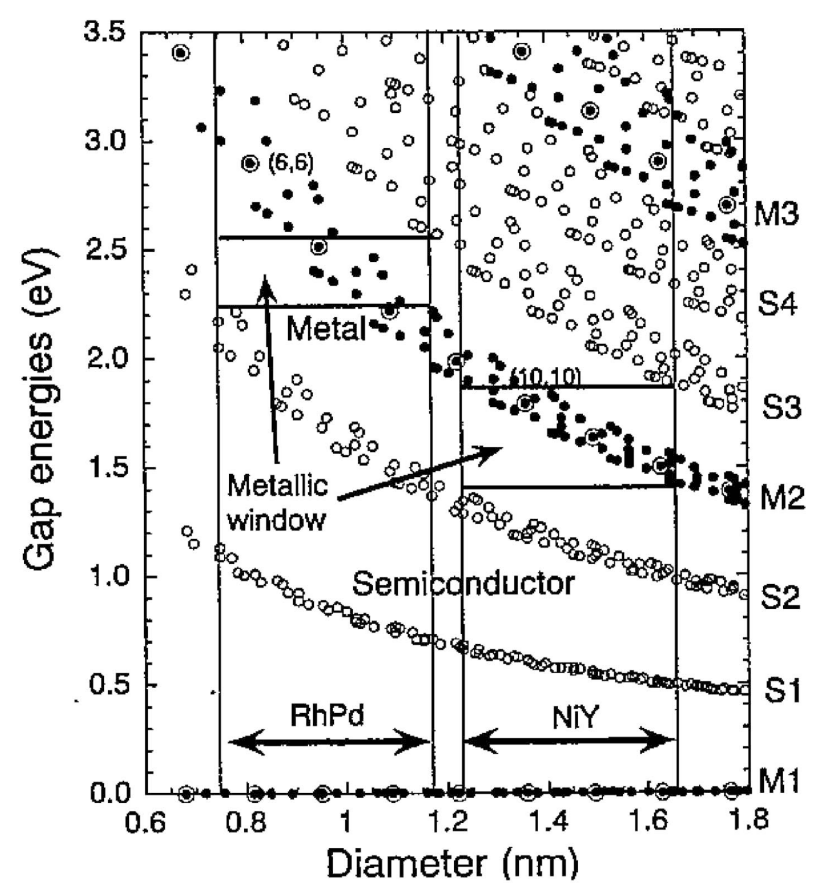

Fig. 2 The values of gap energy are plotted for possible configurations as a function of the diameter. (Kataura's plot). The plop is reproduced from Ref. 33 with permission of Optical Society of Japan.

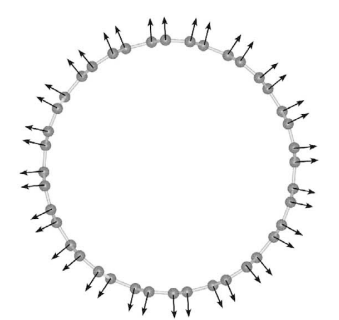

(a) $A_{1 \mathrm{~g}} 165 \mathrm{~cm}^{-1}$

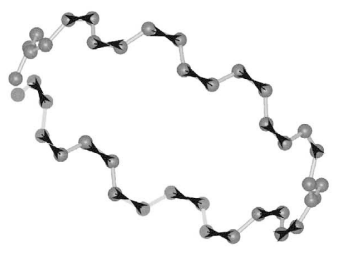

(b) $A_{1 \mathrm{~g}} 1587 \mathrm{~cm}^{-1}$

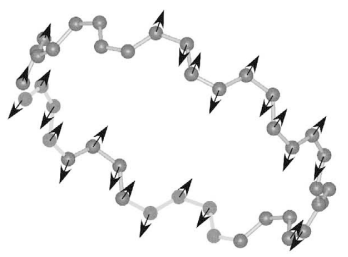

(c) $E_{1 \mathrm{~g}} 1585 \mathrm{~cm}^{-1}$

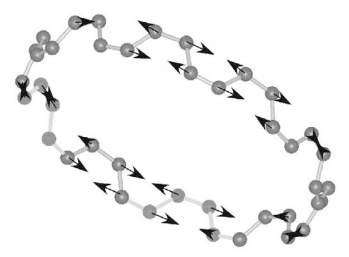

(d) $E_{2 g} 1591 \mathrm{~cm}^{-1}$

Fig. 3 The calculated Raman mode atomic displacements, frequencies, and symmetries for those $(10,10)$ nanotube modes. The freguencies are taken from Ref. 4. 
ペクトルからフォノンのエネルギーや寿命に関する情報が得 られる。

CNTのラマン分光では様々なスペクトルが観測され る ${ }^{4,36)}$. Fig. 4 にCNTのラマンスペクトルを示す. 代表的 なスペクトルとして, ナノチューブの直径が振動するラジア ルブリージングモード (Radial Breathing Mode/RBM)

(Fig. 3(a)), 炭素伸縮振動に由来する G モード (Fig. 3(b)$3(\mathrm{~d}))$, 欠陥に由来する $\mathrm{D}$ モードが挙げられる. 以下, 各振 動モードについて述べる.

\subsubsection{RBM}

ゾーンフォールディングによって新たに許容になった振動 モードで， $100-300 \mathrm{~cm}^{-1}$ の低周波数領域に振動数を持つ (Fig. 4 の挿入図). RBM は軸を中心として, チューブ全体 の直径が伸縮振動することから全対称（A）の対称性を持つ (Fig. 3(a)).このスペクトルが観測されれば，試料中にナ ノチューブが存在しているということができる. RBMの周 波数は CNTの直径に反比例するので37), RBM の周波数か ら観測しているナノチューブの直径を決定することができる.

\subsubsection{G mode}

炭素伸縮振動に由来するラマン活性モードで, $1585 \mathrm{~cm}^{-1}$ 付近にあらわれる (Fig. 4). G モードのスペクトルを詳し く見ると, 単一のローレンツ型のスペクトルではなく, 複数 のスペクトルが重なり合った複雑な構造をもつ $35,38,39)$.この スペクトルの構造は, グラファイトのフォノン分散曲線を使 って説明できる. ブリルアン領域の中心である $\Gamma$ 点で縮退 していたグラファイトの縦光学モードと横光学モードは, チ ューブの曲率効果によってその縮退が解かれる. その結果, $\mathrm{CNT}$ の $\mathrm{G}$ モードは $\mathrm{G}^{+}$と $\mathrm{G}^{-}$の 2 つのスペクトルに分裂す る40-42). さらに, ゾーンフォールディングの結果, これら 2 つのモードは $\mathrm{A}, \mathrm{E}_{1}, \mathrm{E}_{2}$ の対称性をもつモードに分かれる (Fig. 3(b)-3(d) ) ${ }^{35)}$. G モードの対称性に関しては2.2.5節 で更に詳しく説明する.

\subsubsection{D mode}

$1350 \mathrm{~cm}^{-1}$ にあらわれるラマン信号で, サンプルの結晶性 と密接に関わる (Fig. 4). D モードは $\Gamma$ 点のフォノンでは なく $\mathrm{K}$ 点近くのフォノンが関係する $(q \neq 0)$. 欠陥が多いサ ンプルの場合は D バンドの強度が大きくなることから ${ }^{43)}$,

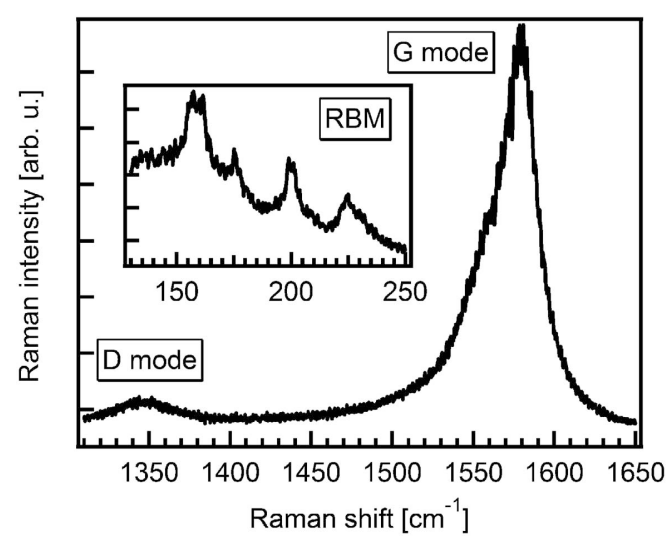

Fig. 4 Raman spectrum of single-walled carbon nanotube. Inset shows the spectrum of RBM.
$\mathrm{D}$ モードと $\mathrm{G}$ モードの相対強度を用いて試料に含まれる欠 陥の量の大まかな評価ができる. D モードは, その倍音に 対応して $2700 \mathrm{~cm}^{-1}$ 付近にラマンシグナルが観測される ( $\mathrm{G}^{\prime}$ モード).

\section{2 .4 共鳴ラマン過程}

本節では共鳴ラマン過程に関してさらに詳しく述べる. 共 鳴ラマン効果では, 入射光または散乱光のいずれかが CNT の光吸収 (放出) のエネルギーに一致する. その結果, 共鳴 ラマン効果が起き, 非常に強いラマン強度が得られる. Fig. 5 に共鳴ラマンの概念図を示した ${ }^{44)}$. 図中の交差する直線は グラファイトのブリルアン領域の $\mathrm{K}$ 点周りの電子状態のエ ネルギー分散関係であり, 交差点が $\mathrm{K}$ 点でフェルミエネル ギーになる. 可視領域の光に対しては, $K$ 点の周りで光吸 収が起きる. 電子のエネルギー分散上に中間状態がある場合 が共鳴状態に対応する (黒丸). 例えば, 入射光共鳴 (Fig. 5 (a)）の場合には, 入射光のエネルギーが励起状態に共鳴 した後, フォノンを放出しフォノンのエネルギーだけエネル ギーが小さくなった光を放出する. 以上は, 光とフォノンと の散乱が 1 回起こる 1 次ラマン過程である. 1 次のラマン過 程では電子とホールの再結合によって発光過程を与えるた め, 入射光の電子の波数 $k$ の状態に再び戻らなければならな い. 光の波数べクトルの大きさがフォノンのそれよりはるか に大きいことから，1次ラマン過程ではフォノンの波数べク トルが $q \sim 0$ に限られる ${ }^{45)}$. したがって観測されるフォノン は $G$ 点のフォノンになる. $G$ 点のフォノンである $\mathrm{RBM}$ や $\mathrm{G}$ モードは 1 次のラマン過程によって生成される.

一方， $\mathrm{D}$ モードは $\mathrm{K}$ 点回りのフォノンなので波数ベクト ル $q$ が 0 ではない. よって, 1 次のラマン過程ではその生成 機構を説明することができない.そこで齋藤（理）は D モー ドの生成機構として 2 次のラマン過程である 2 重共鳴ラマ ン過程（double resonance）を用いて説明した（Fig. 5(c)$5(\mathrm{f}))^{44)}$. 2 重共鳴ラマン過程では, (1)光を $k$ で吸収し，(2) 波数 $q \neq 0$ のフォノン（または欠陥）によって $k+q$ の状態 に散乱され，(3)続いて欠陥（またはフォノン）との散乱によ ってフォノン（または欠陷）とは逆向きの $q$ で散乱され $k$ の

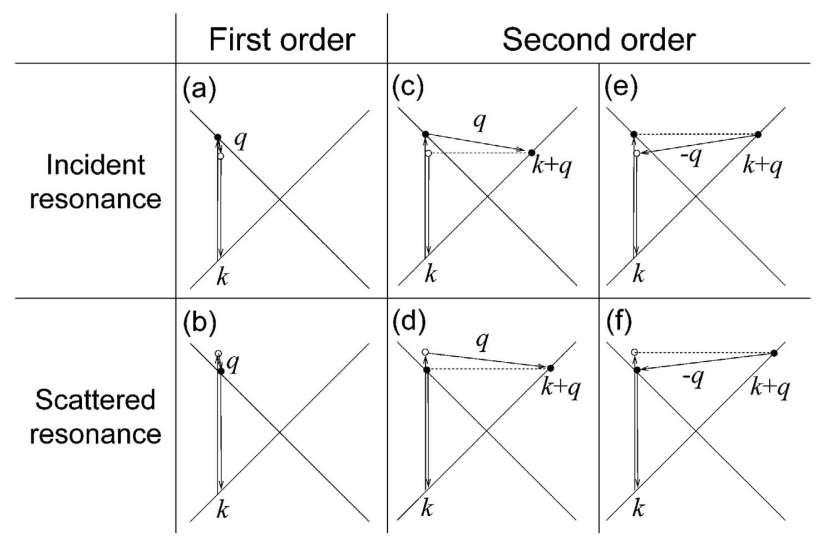

Fig. 5 Schematic diagram for (a) and (b) first order resonant Raman, and (c)-(f) double resonant Raman processes proposed by Saito in Ref. 28. (up) incident light resonance and (down) scattered light resonance. Solid dots are resonance energy states. 
状態に戻り，(4) $k$ で再結合して散乱光を放出する. 2 回の散 乱過程のうち, 1 回はフォノンを出し（実線, エネルギー変 化あり), もう 1 回は弾性散乱（点線, エネルギ一変化なし) である.よって, 実験で観測されるラマンシフトはフォノン を 1 回放出する場合と同じように見える. 以上の過程では $k$ と $k+q$ に抢いていずれも共鳴状態を経ていることから（2 重共鳴ラマン), $\mathrm{D}$ モードも 1 次のラマン散乱と同程度の強 度で観測される。

\section{2 .5 偏光ラマン}

フォノンの対称性は, ラマン強度の偏光解析 (偏光ラマン) を行うことで同定できる. 本節ではフォノンの対称性とラマ ン強度との関係に関して述べる。

ラマン強度 $I_{\mathrm{R}}$ は入射光の光電場を $\mathbf{e}_{\mathrm{S}}$, 散乱光の光電場を $\mathbf{e}_{\mathrm{L}}$ とすと

$$
I_{\mathrm{R}} \propto\left|\mathbf{e}_{\mathrm{S}} \cdot \underline{\alpha} \cdot \mathbf{e}_{\mathrm{L}}\right|^{2}
$$

で与えられる.ここで $\alpha$ はラマンテンソルである ${ }^{45)}$. ラマ ンテンソルはフォノンの対称性によってその形が決まってお り，全対称性（A）のモードでは対角項が，全対称ではない モード $\left(\mathrm{E}_{1}, \mathrm{E}_{2}\right)$ では非対角項が 0 でない值をとる ${ }^{46)}$. G モー ドは $\mathrm{A}$ だけでなく $\mathrm{E}_{1}, \mathrm{E}_{2}$ の対称性のモードをもつことから, $\mathrm{CNT}$ 軸に対して入射光や散乱光の偏光をうまく選べば $\mathrm{G}$ モードの特定の対称性を持つフォノンを選択して観測するこ とができる。

実際，Jorio らは孤立した 1 本の CNTに関して偏光ラマ ン測定を行い, $\mathrm{G}$ モードの $\mathrm{E}_{1}$ と $\mathrm{E}_{2}$ 対称性のモードの検出 することに成功した ${ }^{38,39)}$. しかしながら, それらの強度は $\mathrm{A}$ 対称性に比べると非常に弱かった. Gommans らは, 複数本 のCNT が束になったサンプルに対して偏光ラマン測定を行 ったところ，RBM， G モード，Dモード，いずれのモード も同じ偏光依存性を示した ${ }^{47)}$. 得られた結果はラマンテン ソルの対角成分のみが 0 でないことを仮定した場合によく 再現できた．ラマンテンソルに非対角成分が含まれていない ということは, 観測されたフォノンのモードが A 対称性で ある事を意味する。これは, 複数本の CNT が束になった試 料では CNT 軸の向きが不完全で対称性の特性が検出できな かったためと考えられる。

以上ををとめると， $\mathrm{E}_{1}, \mathrm{E}_{2}$ 対称性など全対称でないフォノ
ンのモードのラマン強度は全対称性（A）のそれに比べると 非常に弱く, ラマン分光では RBM, G モード, D モード, 全てのモードが同じ偏光依存性を示す傾向にある.

\section{3. コヒーレントフォノン}

ラマン分光法ではフォノンのエネルギー領域のスペクトル からキャリア・フォノン相互作用に関する知見を得ることが 出来る. 一方, コヒーレントフォノンではフォノンの実時間 観測を通じて得られた時間領域のスペクトルからキャリア . フォノンダイナミクスに関する知見を得ることができる.

コヒーレントフォノンは通常, 超短パルスレーザを用いた ポンプ・プローブ法を用いて検出される ${ }^{48,49)}$. この手法で は, ポンプ光に対して遅延時間をおいてプローブ光を入射 し, プローブ光の光学定数の変化を遅延時間の関数として表 示する.こうして得られた時間領域のフォノンのスペクトル から, フォノンの周波数, 寿命, 初期位相の情報を得ること ができる. また時間分解フーリエ解析を用いればキャリアや フォノンの過渡的な変化も調べることができる.

コヒーレントフォノンの検出には, 反射, 透過型ポンプ. プローブ測定法, 縮退四波混合, 第 2 高調波発生などの方 法が挙げられる.ここでは, 反射, 透過型ポンプ・プローブ 測定法によるコヒーレントフォノンの測定原理, 実験装置, 測定に用いた試料について以下に述べる.

\section{1 原理}

観測される時間領域のスペクトルは通常，3つの成分から 構成される. Fig. 6 (a)にグラファイトの時間分解反射率測 定の結果を示す. Fig. 6(a)では(1)遅延時間 0 でレーザ光の 自己相関成分による反射率変化が鋭い立ち上がりを見せた後,

(2)励起キャリアの緩和による無振動成分に(3)コヒーレントフ オノンに由来する振動成分が重畳して観測される.この振動 成分 $\Delta R(t)$ はフーリエ変換で周波数領域のスペクトル $\Delta R(\omega)$ に変換することで, ラマン分光によって得られたス ペクトルと直接比較することができる（Fig. 6 (b)). 実際,

Fig. 6(b)で観測されたグラファイトのコヒーレントフォノ ンの周波数はラマン分光で測定される周波数 $\left(42 \mathrm{~cm}^{-1}\right.$ と $\left.1582 \mathrm{~cm}^{-1}\right)^{50)}$ にほぼ一致する.

光学応答にフォノンの振動成分が含まれる理由は, 電子系 (a)

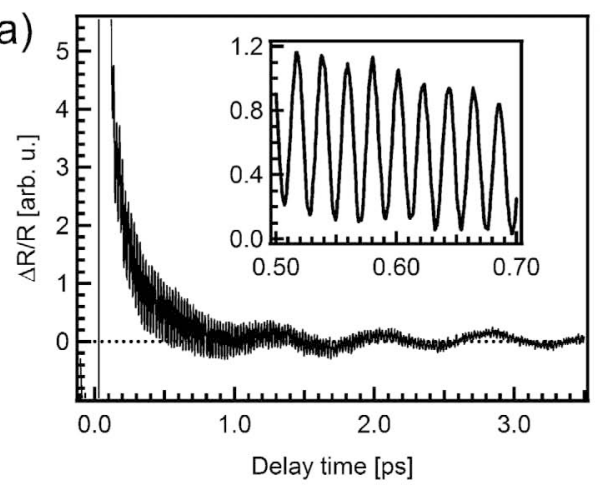

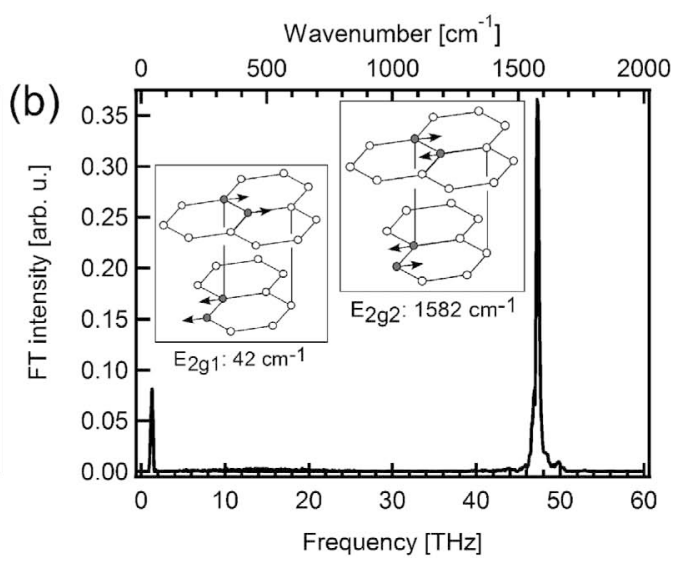

Fig. 6 (a) Time-resolved reflectivity of graphite detected by 780-nm excitation. Inset shows the oscillatory signal of G mode. (b) Fourier transform (FT) spectrum of the oscillatory signal of Fig. 6(a). Insets show the vibration modes in graphite. 
と格子系の相互作用によるものと考えられる.フォノンによ って原子核の平衡位置の変移が起きると, キャリアとの相互 作用を通じて電子状態が变わり, その変化がプローブ光の波 長領域の分極 $\chi$ を変えるため反射率 $R$ が変調を受ける. $Q$ を原子核の平衡位置の変移の一般座標とすると, コヒーレン トフォノンによって生じる反射率の変化 $\Delta R$ は

$$
\Delta R \sim\left(\frac{\partial R}{\partial \chi}\right) \cdot\left(\frac{\partial \chi}{\partial Q}\right) \cdot Q \sim\left(\frac{\partial R}{\partial \chi}\right) \cdot \underline{\alpha} \cdot Q:
$$

で表される ${ }^{49)}$. (2)式にラマンテンソル $\alpha$ が含まれることか ら, レーザ光の偏光や反射光の検出方法によって対称性の異 なるフォノンを選択的に検出することが出来る49,51).

瞬間的な励起によって位相のそろった振動をするコヒーレ ントフォノンはランダムな熱振動とは違い, 統計的平均をと っても相殺されない. よって巨視的な物理量（分極率や反射 率）に拈いて観測可能な变化を引き起こす.

\section{2 実験装置}

測定に用いた反射型ポンプ・プローブ型測定システムの概

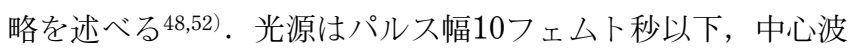
長約790 nm のチタン・サファイアレーザを用いた。レーザ 光を, $\mathrm{BBO}$ 結晶へ集光して得られた第 2 高調波（中心波長 $395 \mathrm{~nm}$ ，パルス幅10フェムト秒以下）をポンプ光ならびに プローブ光として用いた ${ }^{53)}$. 試料上では, ポンプ光の出力 は最大 $40 \mathrm{~mW}$, プローブ光の出力は $3 \mathrm{~mW}$ であった. 試料 からの反射光は, フォトダイオードで光電流として検出した.

試料から反射光の検出方法として, 等方検出法 (isotropic detection) と非等方検出法 (anisotropic detection) の 2 種 類を用いた ${ }^{54,55)}$. 等方検出法では試料に入射する前と後のプ ローブ光の差 $(\Delta R)$ を取る方法で, 試料内部で生じた等方 的な反射率の過渡変化を観測することができる. 観測された 過渡反射率変化には，主に等方的な空間分布をとるキャリア や全対称性のフォノンからの応答が観測される. 一方, 非等 方検出法では試料から反射されたプローブ光は偏光ビームス プリッタによって縦偏光成分 $\left(R_{/ /}\right)$と横偏光成分 $\left(R_{\perp}\right)$ に 分離し, それらの差 $\left(\Delta R_{\mathrm{eo}}=R_{/ /}-R_{\perp}\right)$ を取る. 差を取るこ とで, 試料内部に生じた等方的な反射率成分を打ち消すこと ができる，そのため，等方的な反射率成分に隠れて観測する ことのできなかった異方的な反射率の変化を取り出すことが できる，観測された反射率変化には，非等方に分布するキャ リアや主に対称性の低いモードからの応答が観測される。こ れら 2 つ検出方法を使い分けることで, 対称性の異なる フォノンを選択的に観測することができる.

\section{3 試料}

試料はレーザアブレーションによって合成した単層カーボ ンナノチューブ (single-walled carbon nanotube/SWCNT) を用いた. SWCNTをアルコール溶液に分散させ, 分散液 に石英基板を浸し，引き上げ法によって試料を作成した．こ のようにして作成した SWCNT は，基板を溶液から引き上 げるときに界面にそって自己配列（self-assembly）が起きて 軸が一方向に配列する ${ }^{56)}$. 実際, 偏光ラマンや電子顕微鏡 の観測で試料が配列していることを確認することができた.

石英基板上に CNT を配列させたのは反射光を得るのに適 しているからである. 溶液中に分散した試料 21,57$)$ や高分子の
フィルム中に分散した試料20)でも CNT のコヒーレントフォ ノンを観測することができる。

\section{4. 単層カーボンナノチューブのコヒーレントフ オノン}

本章では, サブ10フェムト秒レーザを用いた超短パルス レーザによる単層カーボンナノチューブの時間分解反射率の 測定結果に関して述べる22).

\section{1 アンテナ効果}

2.1節で述べたと抢り, 光の偏光が SWCNT 軸に平行な場 合は強い吸収が起きる (アンテナ効果). 実際, プローブ光 の偏光を SWCNT 軸に対して回転させながらその反射率を 測定したところ, 強い偏光依存性を観測することができた

(Fig. 7). $\theta$ は SWCNT 軸とレーザ偏光のなす角度である. $\mathrm{CNT}$ の軸に偏光が平行な場合は $\left(\theta=0^{\circ}\right)$ 吸収が大きくなる ため反射率は最小となり (アンテナ効果), 垂直な場合は $(\theta$ $=90^{\circ}$ ), 吸収が小さくなるため反射率は最大となる（偏光解 消効果) ${ }^{58,59)}$. 測定に用いた試料で CNTの軸がそろってい ることを確認することができた。

\subsection{SWCNT のコヒーレントフォノンにおける等方検出 之非等方検出}

次にSWCNTの時間分解反射率の結果を示す。 Fig. $8(\mathrm{a}), 8(\mathrm{~b})$ は等方検出法ならびに非等方検出法による測定 結果である. いずれの検出法でも遅延時間 0 にレーザ光の 自己相関成分による鋭い立ち上がりが観測された。その後, 等方検出法ではキャリアによる非振動成分にフォノンの振動 成分が重畳した信号が検出された (Fig. 8(a)). 一方, 非等 方検出では等方的な反射率変化を与えるキャリアによる非振 動成分が取り除かれ，フォノンによる反射率変化が観測され た (Fig. 8(b)).

フォノンによる反射率の振動成分をフーリエ変換して得ら れたスペクトルを Fig. 8(c)，8(d) に示す. 等方検出で得ら れたスペクトル (Fig. 8(c)) には, (1) $300 \mathrm{~cm}^{-1}$ 以下の低い 振動成分, (2) $1350 \mathrm{~cm}^{-1}$, (3) 1560-1580 $\mathrm{cm}^{-1}$ の 3 つの領域 でピークが観測された，一方，非等方検出で得られたスペク トル (Fig. 8(d)) には(3) 1560-1580 cm-1 の最も高い振動

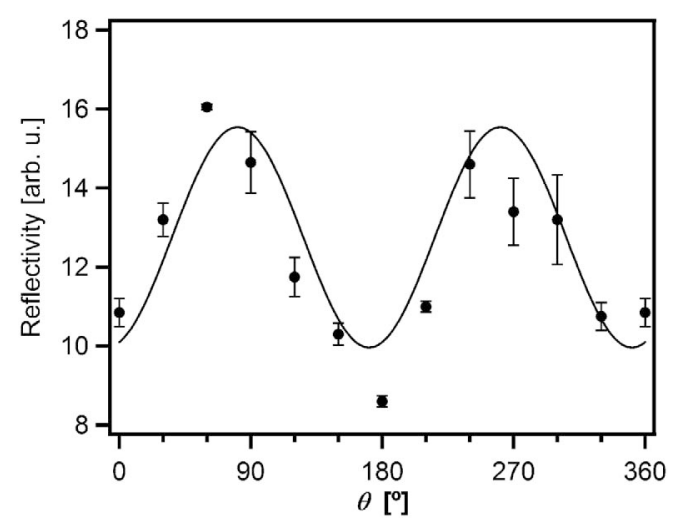

Fig. 7 Polarization dependence of the reflectivity. Solid circles are experimental results plotted as a function of the angle $(\theta)$ between the laser polarization and the axis of CNTs. The solid line is a fit to the $\cos (2 \theta)$ function. 

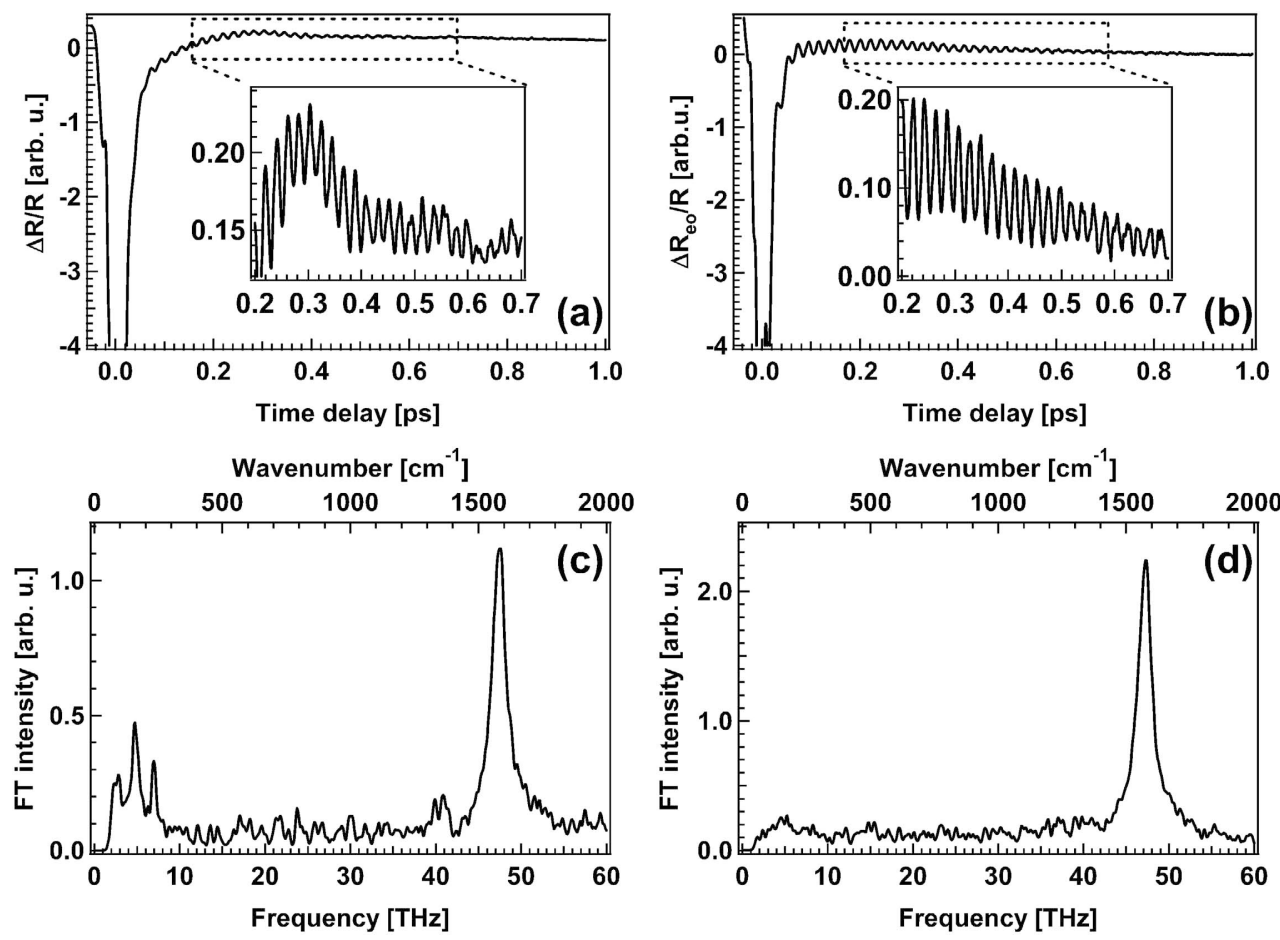

Fig. 8 Time-resolved reflectivity of SWCNTs taken with the (a) transient reflectivity and (b) EO sampling. The inset is the enlarged signal for the oscillatory components. FT spectrum of the time-resolved reflectivity of SWCNTs taken with the (c) transient reflectivity measurement and (d) EO sampling.

数の成分しか観測されなかった.コヒーレントフォノンで観 測されたフーリエスペクトルとラマン分光で得られた周波数 領域のスペクトル4)を比較すると(1) RBM，(2) D モード，(3) $\mathrm{G}$ モードと同定することが出来る. 以下，各モードに関して 更に詳しく説明しよう。

RBM で観測された複数のピークは，試料中に，異なる直 径のSWCNTそれぞれのRBMに由来する．観測されたフ オノンの周波数から CNT の直径を見積もったところ $1.0 \pm$ $0.1,1.4 \pm 0.2,1.6 \pm 0.2 \mathrm{~nm}$ であった ${ }^{37)}$ 。これらの直径の SWCNT に対し $3.1 \mathrm{eV}$ の光を照射したときは, 片浦プロッ トから半導体，金属いずれの SWCNT も共鳴励起されうる ことがわかる ${ }^{32}$. RBM は等方検出での反観測されたが，こ れは RBM が空間的に等方な運動をする全対称モードである ためと考えられる.

$\mathrm{D}$ モードも RBM と同様，等方検出での久観測された。 $\mathrm{D}$ モードの起源が試料内の欠陥であることから，ランダムに分 布する欠陥による振動が等方的な反射率変化を生及出したと 考えられる. ラマン分光で観測されたのと同様, D モード のコヒーレントフォノンが 2 次のラマン過程を経ていると すると, Dモードのコヒーレントフォノンの観測は $q \neq 0$ の フォノンでもコヒーレントフォノンが観測できることを意味 する.この結果は, 何がコヒーレントフォノンを“コヒーレ ント”たらしめているかという疑問に対する答えを提示す る.これまでに“コヒーレントフォノンが観測できる”必要 条件として, Kuznetsovは「 $q=0$ であること」60)を，Kurz は「各フォノンが一斉にそろって運動すること」61,62)を挙げ て抢り，統一した見解にいたっていなかった．コヒーレント な D モードの観測結果は「コヒーレントフォノンが観測で

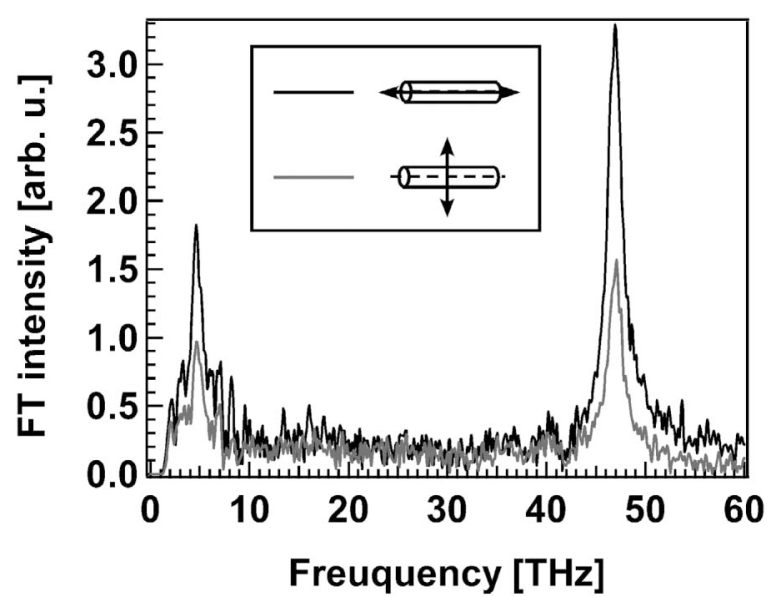

Fig. 9 FT spectrum of the time-resolved reflectivity of SWCNTs when both the pump and the probe polarizations are parallel (black) or perpendicular (gray) to the axis of SWCNTs.

きる」必要条件に「 $q=0$ であること」は必ずしも含まれな いことを示唆する.

他の 2 つのモードとは対照的に, $\mathrm{G}$ モードはいずれの検 出方法でも観測することができた。これは $\mathrm{G}$ モードが全対 称 $(\mathrm{A})$ モードだけでなく, 他の対称性 $\left(\mathrm{E}_{1}\right.$ や $\left.\mathrm{E}_{2}\right)$ のモー ドを持つためと考えられる. G モードの対称性に関し, 更に 詳しく4.4節で述べる.

\section{3 コヒーレントフォノンにおけるアンテナ効果}

電子遷移で観測されたアンテナ効果は, ラマン強度に影響 を及ほすことが知られている ${ }^{10,47)}$. 実際, CNT 軸に対して 
ポンプ光を平行に入射した場合と垂直に入射した場合を比較 すると，平行に入射したほう（Fig.9 黒）が垂直に入射し たとき（Fig. 9 灰色）より，いずれのフォノンのモードも大 きな振幅を示した．以上の結果から，コヒーレントフォノン
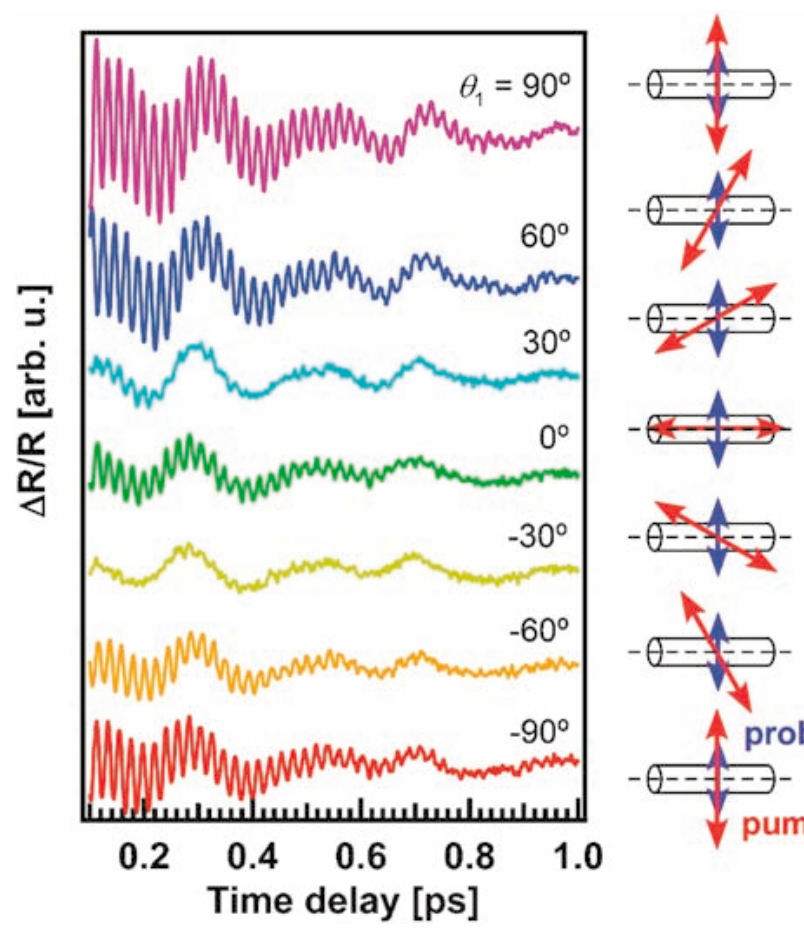

Fig. 10 Time-resolved measurements of $\Delta R / R$ taken by rotating the polarization direction of the pump laser (red). The polarization direction of probe laser (blue) is set to be perpendicular to the axis of CNTs.
の振幅に㧍いてもアンテナ効果が起きることがわかる.

\section{4 コヒーレントフォノンの偏光依存性}

コヒーレントフォノンでは RBM と G モードで異なる偏 光依存性が観測された。一方，2.2.5節で前述したと抢り偏 光ラマンでは, いずれのフォノンのモードも $\mathrm{A}$ 対称性の偏 光依存性を示した.ここではコヒーレントフォノンの偏光依 存性について紹介する.

Fig. 10 にポンプ光の偏光を CNT 軸に対して回転したと きの過渡反射率の変化を示す. CNT 軸に対するポンプ光の 偏光の角度を $\theta_{1}$ とすると, $\mathrm{RBM}$ に由来する遅い振動はい ずれの角度でも観測されたが， $\mathrm{G}$ モードに由来する速い振動 の振幅は強い角度依存性示し, 特に $\theta_{1}= \pm 30^{\circ}$ のときに消失 した.

各モードの偏光依存性を調べるためにフーリエ解析を行っ たとの結果をFig. 11(a)に示す．Fig. 11(a)から，Gモー ドの振幅は $\theta_{1}= \pm 90^{\circ}$ で最大となり， $\theta_{1}= \pm 30^{\circ}$ で最小となる ことがわかる. G モードと RBM の積分強度の比 $\left(I_{\mathrm{G}} / I_{\mathrm{RBM}}\right)$ をポンプとプローブの偏光のなす角度 $\left(\theta_{1}-\theta_{2}\right)$ の関数とし て表示した（Fig. 11(b)の赤丸）。ここで $\theta_{2}$ は CNT 軸に対 するプローブの偏光の角度である. $I_{\mathrm{G}} / I_{\mathrm{RBM}}$ は $\theta_{1}-\theta_{2}=0^{\circ}$ と $180^{\circ}$ で最大值を取り， $\theta_{1}-\theta_{2}=60^{\circ}$ と $120^{\circ}$ でほぼ 0 になり, $\theta_{1}-\theta_{2}=90^{\circ}$ で極值を取ることがわかった．比較のためにグ ラファイトの G モードの偏光依存性の結果も併せて表記し た（Fig. 11(b)の黒丸). 観測されたグラファイトの G モー ドは, $\mathrm{E}_{2 \mathrm{~g}}$ 対称性のラマンテンソルから予想される通り $\mid \cos$ $\left.\left(2\left(\theta_{1}-\theta_{2}\right)\right)\right|^{2}$ の依存性を示した ${ }^{63,64)}$.

2.2節で述べたとおり，CNTの格子振動はグラファイトの 基準振動が基本となっており，グラファイトでは光学的に許

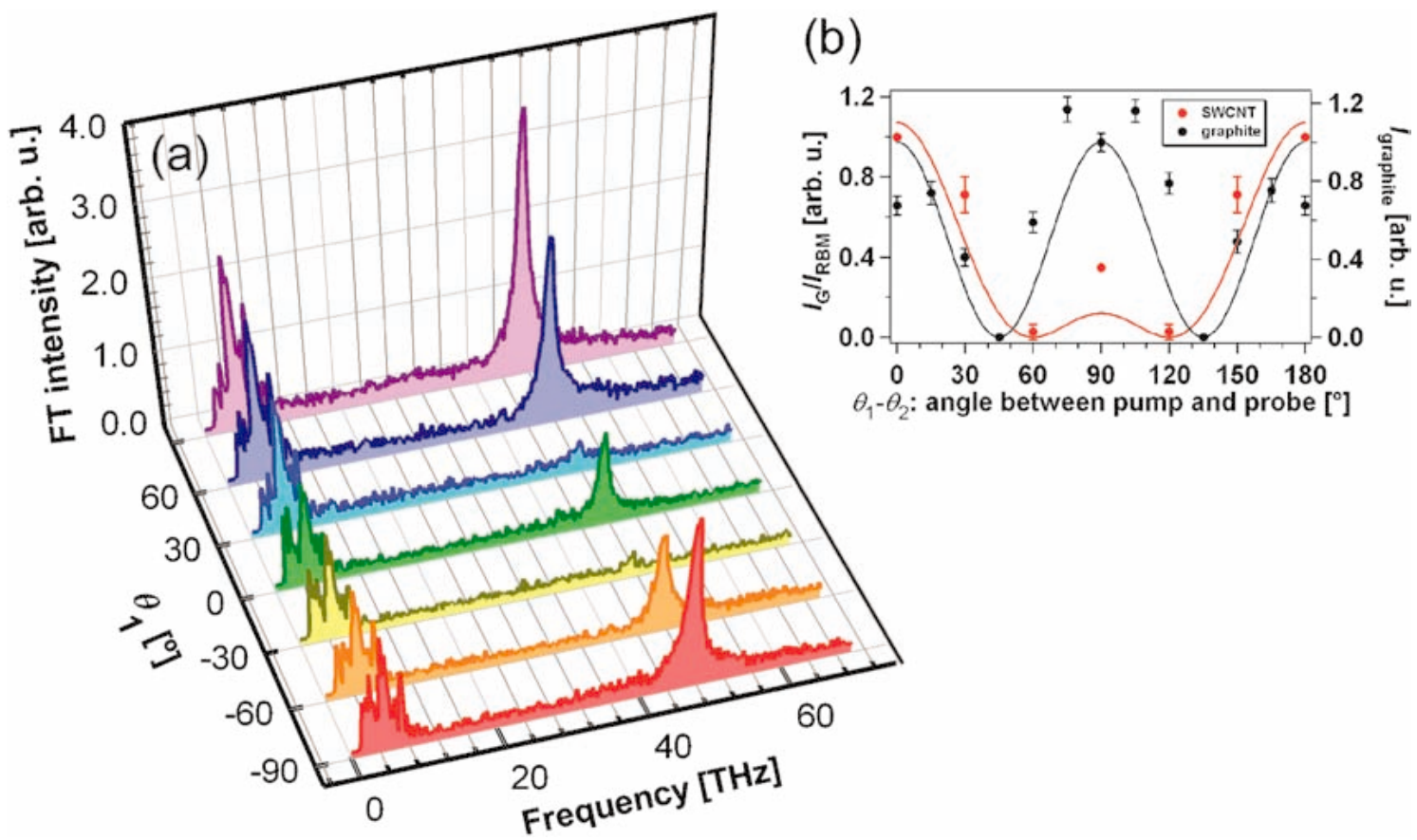

Fig. 11 (a) FT spectrum of $\Delta R / R$ in Figure 10. The color of each plot corresponds to the FT spectrum with the same color shown in Figure 10. (b) Solid red circles give the ratio of the integrated intensity of the G mode and RBM, $I_{\mathrm{G}} / I_{\mathrm{RBM}}$, is plotted as a function of the angle between pump and probe. The solid red line is the fitting result with $\left|\alpha+\beta \cos \left(2\left(\theta_{1}-\theta_{2}\right)\right)\right|^{2}$ where $\alpha / \beta=0.5$. For comparison, solid black circles give the polarization dependence of graphite as a function of the angle between the pump and the probe. The solid black line is the fitting result for graphite with $\left|\cos \left(2\left(\theta_{1}-\theta_{2}\right)\right)\right|^{2}$. 


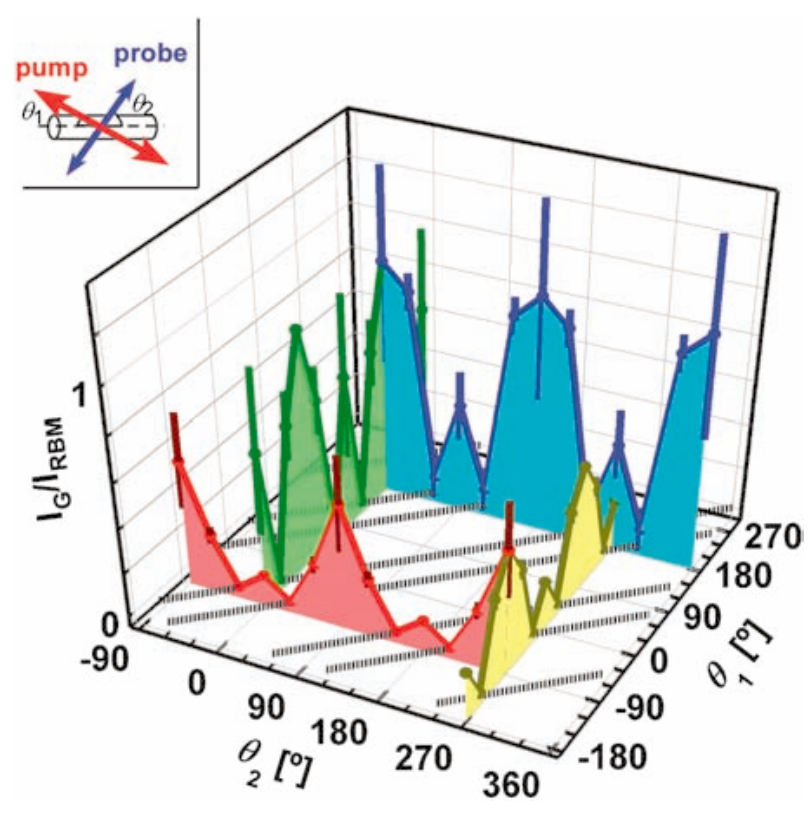

Fig. 12 Polarization dependence of $I_{\mathrm{G}} / I_{\mathrm{RBM}}$ plotted as a function of $\left(\theta_{1}, \theta_{2}\right)$ where $\theta_{1}\left(\theta_{2}\right)$ is the angle of pump (probe) polarization with respect to the axis of SWCNTs. Dotted lines connect between points where $I_{\mathrm{G}} / I_{\mathrm{RBM}}$ nearly equals zero.

容されていない振動数が $\mathrm{CNT}$ では $\Gamma$ 点の新たな振動モード として許容振動になる. Fig. 11(b)でグラファイトとCNT の偏光依存性が一致しなかったことは, CNT の G モードで 観測された偏光依存性に折り曲げで新たに許容となった別の 対称性を持つフォノンが関与していることを示唆する.

更に詳しくSWCNT のコヒーレントフォノンの偏光依存 性を調べために，他の偏光配置で測定を行い $I_{\mathrm{G}} / I_{\mathrm{RBM}}$ を $\left(\theta_{1}\right.$, $\left.\theta_{2}\right)$ の関数として表示した（Fig. 12）. Fig. 12から $I_{\mathrm{G}} / I_{\mathrm{RBM}}$ はポンプ光とプローブ光のなす角度 $\left|\theta_{1}-\theta_{2}\right|$ に強く依存し ていることがわかった. $\left|\theta_{1}-\theta_{2}\right|=0^{\circ}$ または $180^{\circ}$ ，つまりポ ンプとプローブ光が平行なときには $I_{\mathrm{G}} / I_{\mathrm{RBM}}$ は最大となり, $\left|\theta_{1}-\theta_{2}\right|=60^{\circ}$ また $120^{\circ}$ のときは $I_{\mathrm{G}} / I_{\mathrm{RBM}}=0$ となることが わかった．また $\left|\theta_{1}-\theta_{2}\right|=90^{\circ}$, つまりポンプ光とプローブ 光が互いに垂直なときには極值を取ることもわかった，通常 の物質で観測されるコヒーレントフォノンは $\cos (2 \theta), \sin$ $(2 \theta)$, または一定（すなわち依存性なし）などの偏光依存 性を見せる ${ }^{63,64)}$ 。すべての偏光配置を測定したわけではない が, $\left|\theta_{1}-\theta_{2}\right|=60^{\circ}$ また $120^{\circ}$ でフォノンの振幅が 0 になるこ とは SWCNT の偏光依存性の特徵であるといえる.

$\mathrm{G}$ モードの特異な偏光依存性の起源を明らかにするため

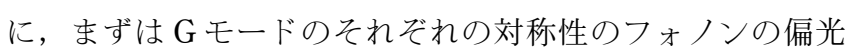
依存性について考える. ポンプ光が $x$ 軸方向に伝播し,

$\mathrm{CNT}$ の軸が $z$ 軸に平行であるとする. $\mathrm{CNT}$ が $\mathrm{C}_{6}$ 対称性を もつとすると, $y z$ 平面（光電場が振動する平面）のラマン テンソルは $\mathrm{A}, \mathrm{E}_{1}, \mathrm{E}_{2}$ 対称性それぞれ

$$
\mathrm{A}:\left(\begin{array}{ll}
a & 0 \\
0 & b
\end{array}\right), \mathrm{E}_{1}:\left(\begin{array}{ll}
0 & c \\
c & 0
\end{array}\right), \mathrm{E}_{2}:\left(\begin{array}{ll}
d & 0 \\
0 & 0
\end{array}\right):
$$

で表される ${ }^{46)}$. CNT 軸に対するポンプ光の偏光の角度を $\theta$ とすると, 各対称性のフォノンの散乱強度は

$$
\mathrm{A}:|(a+b) / 2+(b-a) / 2 \cdot \cos (2 \theta)|^{2}:
$$

$$
\begin{aligned}
& \mathrm{E}_{1}:|c \cdot \cos (2 \theta)|^{2}: \\
& \mathrm{E}_{2}:|d \cdot(1-\cos (2 \theta)) / 2|^{2}:
\end{aligned}
$$

で与えられる63,65). CNT の偏光ラマンの結果によるとA 対 称性のフォノンのラマンテンソルは $a=0$ であるので位，そ のラマン散乱強度は $|b / 2 \cdot(1+\cos (2 \theta))|^{2}$ となる。 $(4-1)$, $(4-2),(4-3)$ から，いずれの対称性にしても単独では $\theta$ $=60^{\circ}$ または $120^{\circ}$ で偏光依存性が最小になるのは説明できな い.

そこで全ての対称性を重ね合わせた場合を考える，その場 合, フォノンの散乱強度は,

$$
d S / d \Omega \propto|\alpha+\beta \cos (2 \theta)|^{2}:
$$

で表される65)。ここで $\alpha$ と $\beta$ は $b, c, d$ を使って与えられ る. 実際, 実験で得られた結果（Fig. 11(b)の赤丸）を(5) 式でフィットすると $\alpha / \beta=0.5$ で観測された偏光依存性を再 現することが出来た. 以上から， G モードのコヒーレントフ オノンの偏光依存性は, 異なる対称性を持つフォノンが重な り合いを起こしていることを示唆する.

SWCNT で異なる対称性を持つフォノンの重なり合わせ が起きることはReichらによって, 円偏光を用いた偏光ラ マンの実験結果から指摘されていた66). 今回観測されたコ ヒーレントフォノンの偏光依存性は, 対称性の異なるフォノ ン（Fig. 3(b)-3(d)）の重なり合わせを実時間で観測したこ とに相当する. G モードのフォノンの周波数が互いに非常に 近接していることを考えると, フォノンの振幅が消失したの は, 異なる対称性を持つフォノンが異なる初期位相もって振 動し, 打ち消しあいが起きた結果と推測する.

\section{5. 展望}

コヒーレントフォノンは, 熱的に励起されてバラバラに運 動する通常のフォノンとは異なり, 位相が揃っているという 特長を有する。この特長を生かし, フォノンの運動を制御す ることも可能である.

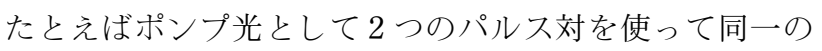
振動数を持つ 2 組のコヒーレントフォノンを発生させれ ば，これらを干渉させることが出来る．2つのパルス間の時 間間隔を変えることでフォノンの振幅を強くしたり, 打ち消 したり出来る．Kim らはこの技術を用い, 様々な直径をも つ CNT の試料で特定の振動数を持つ RBM を選択的に励起 することに成功した ${ }^{24,25)}$ ：この技術を用いれば，螺旋度を選 択したCNT の物性研究やCNT のチューブ末端にあるキャ ップの開環反応 67,68$)$ を誘起することができるであろう.

特にキャップの開環反応に関しては, CNT を利用したド ラッグデリバリーに用いることが出来るのではないかと考え る、抗がん剤などの薬剤を患部へ輸送する方法（ドラッグデ リバリー）として, 薬剤を内包させたカーボンナノチューブ を用い, 更にレーザ光照射よって治療効果を高める研究が 行われている69,70).この際, パルス対を用いてコヒーレント フォノンの振幅を增幅することで, 低い強度で効率良くナノ チューブの開環反応を誘起し、レーザによる損傷の少ないド ラッグデリバリーが期待できる.

レーザの波形整形技術の発展に伴い, 振幅, パルス幅, 偏 光, 位相などさまざまなパラメータの任意制御が可能となっ 
た．格子振動はキャリア輸送特性や構造など物質の特性を支 配する. 次世代のデバイス材料として注目を集める CNTで コヒーレントフォノンを制御することは, CNTの更なる可 能性を開拓するものと期待する.

\section{6. まとめ}

サブ10フェムト秒レーザを用いた時間分解反射率測定に より単層カーボンナノチューブのコヒーレントフォノンを観 測した、等方測定と非等方測定を用いることで RBM, G モード，さらには D モードのコヒーレントフォノンを選択 して観測することができた．またコヒーレントフォノンで観 測された Gモードの特異な偏光依存性は, 異なる対称性を 持つフォノンモードが，異なる初期位相を持って重なり合っ た結果であることを表す。

超短パルスレーザ技術の発展により, 極めて短い時間で起 こるコヒーレントなキャリアやフォノンのダイナミクスを実 時間で観測できるようになった。レーザ波形整形技術を組み 合わせることで, ナノ物質のコヒーレント制御が可能になる と期待する.

\section{謝辞}

本稿は, 筆者らが物質・材料研究機構に在籍中に行った結 果を中心にまとめたものです. 実験の解釈においては齋藤理 一郎教授（東北大学）から貴重な議論をいただきました．実 験にあたっては, Prof. H. Petek (University of Pittsburgh) と行いました. 試料は唐博士 (物資 - 材料研究機構) から提 供を受けました。測定技術に関しては石岡博士（物質・材料 研究機構）にアドバイスをいただきをした，またコヒーレン トフォノン全般に関して, 長谷准教授 (筑波大学), Prof. O. Misochko（ロシア科学アカデミー）から議論をいただき ました．本稿の執筆にあたっては首藤准教授 (横浜国立大学) に打世話になりました，ここに深く感謝いたします. 本研究 は若手研究 B (20750021), 基盤研究 B（21310065）の支援 を受けて行われました。

\section{[文献〕}

1) http://www.intel.co.jp/jp/technology/mooreslaw/index.htm インテルの HP でムーアの法則とプロセッサーを構成するトラ ンジスタの数の関係が年表と共に掲載されている.

2) K. S. Novoselov, A. K. Geim, S. V. Morozov, D. Jiang, Y. Zhang, S. V. Dubonos, I. V. Grigorieva and A. A. Firsov: Science, 306 (2004) 666.

3) S. J. Tans, A. R. M. Verschueren and C. Dekker: Nature, 393 (1998) 49.

4) R. Saito, G. Dresselhaus and M. S. Dresselhaus: Physical Properties of Carbon Nanotubes (Imperial College Press, London, 1998).

5) Y. Saito and S. Bandow: Introduction to Carbon Nanotubes (CORONA Publishing Co., LTD., Tokyo, 1998) [in Japanese].

6) Z. Yao, C. L. Kane and C. Dekker: Phys. Rev. Lett., 84 (2000) 2941.

7) L. Huang, H. N. Pedrosa and T. D. Krauss: Phys. Rev. Lett., 93 (2004) 017403.

8) J.-S. Lauret, C. Voisin, G. Cassabois, C. Delalande, P. Roussignol, O. Jost and L. Capes: Phys. Rev. Lett., 90 (2003) 057404.

9) T. Hertel, R. Fasel and G. Moos: Appl. Phys. A, 75 (2002) 449.

10) A. Jorio, et al.: Phys. Rev. B, 65 (2002) $121402(\mathrm{R})$.
11) M. Freitag, Y. Martin, J. A. Misewich, R. Martel and P. Avouris: Nano Lett., 3 (2003) 1067.

12) Y. Murakami, E. Einarsson, T. Edamura and S. Maruyama: Phys. Rev. Lett., 94 (2005) 087402.

13) J. A. Fagan, et al.: Phys. Rev. Lett., 98 (2007) 147402.

14) J. Lefebvre and P. Finnie: Phys. Rev. Lett., 98 (2007) 167406.

15) K. Kashiwagi, S. Yamashita, Y. Nasu, H. Yaguchi, C. S. Goh and S. Y. Set: Appl. Phys. Lett., 89 (2006) 081125.

16) F. Wang, A. G. Rozhin, V. Scardaci, Z. Sun, F. Hennrich, I. H. White, W. I. Milne and A. C. Ferrari: Nature Tech., 3 (2008) 738.

17) Y.-W. Song, S. Yamashita and S. Maruyama: Appl. Phys. Lett., 92 (2008) 021115.

18) T. R. Shibli, K. Minoshima, H. Kataura, E. Itoga, N. Minami, S. Kazaoui, K. miyashita, M. Tokumoto and Y. Sakakibara: Opt. Exp., 13 (2005) 8025.

19) C. Manzoni, A. Gambetta, E. Menna, M. Meneghetti, G. Lanzani and G. Cerullo: Phys. Rev. Lett., 94 (2005) 207401.

20) A. Gambetta, et al.: Nature Phys., 2 (2006) 515.

21) Y.-S. Lim, K.-J. Yee, J.-H. Kim, E. H. Haroz, J. Shaver, J. Kono, S. K. Doorn, R. H. Hauge and R. E. Smalley: Nano Lett., 6 (2006) 2696.

22) K. Kato, K. Ishioka, M. Kitajima, J. Tang, R. Saito and H. Petek: Nano Lett., 8 (2008) 3102.

23) L. Lüer, C. Badermaier, J. Crochet, T. Hertel, D. Brida and G. Lanzani: Phys. Rev. Lett., 102 (2009) 127401.

24) J.-H. Kim, et al.: Phys. Rev. Lett., 102 (2009) 037402.

25) G. D. Sanders, C. J. Stanton, J.-H. Kim, K.-J. Yee, Y.-S. Lim, E. H. Haroz, L. G. Booshehri, J. Kono and R. Saito: Phys. Rev. B, 79 (2009) 205434.

26) A. M. Rao, et al.: Science, 275 (1997) 187.

27) R. Saito, M. Fujita, G. Dresselhaus and M. S. Dresselhaus: Appl. Phys. Lett., 60 (1992) 2204.

28) R. Saito: TANSO, 205 (2002) 276 [in Japanese].

29) R. Saito: OYO BUTSURI, 70 (2001) 1196 [in Japanese].

30) Y. Wang, et al.: Appl. Phys. Lett., 85 (2004) 2607.

31) H. Ajiki and T. Ando: Physia B, 201 (1994) 349.

32) H. Kataura, Y. Kumazawa, Y. Maniwa, I. Umezu, S. Suzuki, Y. Ohtsuka and Y. Achiba: Synth. Metals, 103 (1999) 2555.

33) H. Kataura: Jap. J. Optics, 30 (2001) 105 [in Japanese].

34) D. Sanchez-Portal, E. Artacho, J. M. Soler, A. Rubio and P. Ordejn: Phys. Rev. B, 59 (1999) 12678.

35) R. Saito, T. Takeya, T. Kimura, G. Dresselhaus and M. S. Dresselhaus: Phys. Rev. B, 57 (1998) 4145.

36) M. S. Dresselhaus and P. C. Eklund: Adv. Phys., 49 (2000) 705.

37) S. M. Bachilo, M. S. Strano, C. Kitterell, R. H. Hauge and R. E. S. R. B. Weisman: Science, 298 (2002) 2361.

38) A. Jorio, et al.: Phys. Rev. Lett., 90 (2003) 107403.

39) A. Jorio, et al.: Phys. Rev. Lett., 85 (2000) 2617.

40) A. Kasuya, Y. Sasaki, Y. Saito, K. Tohji and Y. Nishina: Phys. Rev. Lett., 78 (1997) 4434.

41) A. Jorio, et al.: Phys. Rev. B, 65 (2002) 155412.

42) R. Saito, A. Jorio, J. H. Hafner, C. M. Lieber, M. Hunber, T. McClure, G. Dresellhaus and M. S. Dresselhaus: Phys. Rev. B, 64 (2001) 085312.

43) E. Asari, M. Kitajima, K. G. Nakamura and T. Kawabe: Phys. Rev. B, 47 (1993) 11143.

44) R. Saito, A. Jorio, A. G. S. Filho, G. Dresselhaus, M. S. Dresselhaus and M. A. Pimenta: Phys. Rev. Lett., 88 (2002) 027401.

45) P. Y. Yu and M. Cardona: Fundamentals of Semiconductors (Springer-Verlag, Berlin, 1996).

46) R. Loudon: Adv. Phys., 50 (2001) 813.

47) H. H. Gommans, J. W. Alldredge, H. Tashio, J. Park, J. Magnuson and A. G. Rinzler: J. Appl. Phys., 88 (2000) 2509.

48) S. Nakashima, M. Hase, K. Mizoguchi and H. Harima: J. Surf. Sci. Soc. Jpn., 19 (1998) 64 [in Japanese].

49) T. Dekorsy, G. C. Cho and H. Kurz: Coherent Phonons in Condensed Media (Springer-Verlag, Berlin, 2000). 
50) P. C. Eklund, J. M. Holden and R. A. Jish: Carbon, 33 (1995) 959.

51) K. J. Yee, K. G. Lee, E. Oh, D. S. Kim and Y. S. Lim: Phys. Rev. Lett., 88 (2002) 105501.

52) M. Kitajima, M. Hase and H. Petek: J. Surf. Sci. Soc. Jpn., 26 (2005) 648 [in Japanese].

53) M. Hase, M. Kitajima, A. M. Constantinescu and H. Petek: Nature, 426 (2003) 51.

54） T. Dekorsy, H. Auer, C. Waschke, H. J. Bakker, H. G. Roskos and H. Kurz: Phys. Rev. Lett., 74 (1995) 738.

55) M. Hase, K. Mizoguchi, H. Harima, S. Nakashima, M. Tani, K. Sakai and M. Hangyo: Appl. Phys. Lett., 69 (1996) 2474.

56) H. Shimoda, S. J. Oh, H. Z. Geng, R. J. Walker, X. B. Zhang, L. E. McNeil and O. Zhou: Adv. Matt., 14 (2002) 899.

57) K. Makino, A. Hirano, K. Shiraki, Y. Maeda and M. Hase: Phys. Rev. B., 80 (2009) 245428.

58) M. Ichida, S. Mizuno, H. Kataura, Y. Achiba and A. Nakamura: Appl. Phys. A, 78 (2004) 1117.

59) Y. Kim, N. Minami and S. Kazoui: Appl. Phys. Lett. 86 (2005) 073103.

60) A. V. Kuznetsov and C. J. Stanton: Phys. Rev. Lett., 73 (1994) 3243.
61) W. Kutt, W. Albrecht and H. Kurz: IEEE J. Quantum Electron., 28 (1992) 2434.

62) R. Scholz, T. Pfeifer and H. Kurz: Phys. Rev. B, 47 (1993) 16229 .

63) K. J. Yee, K. G. Lee, E. Oh and D. S. Kim: Phys. Rev. Lett., 88 (2002) 105501

64) K. Ishioka, M. Hase, M. Kitajima, L. Wirtz, A. Rubio and H. Petek: Phys. Rev. B, 77 (2008) $121402(\mathrm{R})$.

65) K. J. Yee, Y. S. Lim, T. Dekorsy and D. S. Kim: Phys. Rev. Lett., 86 (2001) 1630.

66) S. Reich, C. Thomsen, G. S. Duesberg and S. Roth: Phys. Rev. B, 63 (2001) 041401(R).

67) T. Dumitrica, M. E. Garcia, H. O. Jeschke and B. I. Yakobson: Phys. Rev. B, 74 (2006) 193406.

68) T. Dumitrica, M. E. Garcia, H. O. Jeschke and B. I. Yakobson: Phys. Rev. Lett., 92 (2004) 117401.

69) N. W. S. Kam, M. O'Connell, J. A. Wisdom and H. Dai: Proc. Natl. Acad. Sci., 102 (2005) 11600.

70) M. Zhang, T. Murakami, K. Ajima, K. Tuchida, A. S. D. Sandanayaka, O. Ito, S. Iijima and M. Yudasaka: Proc. Natl. Acad. Sci., 105 (2008) 14773. 